\title{
STUDIES ON TISSUE UPTAKE OF INSULIN IN MAN USING A DIFFERENTIAL IMMUNOASSAY FOR ENDOGENOUS AND EXOGENOUS INSULIN *
}

\author{
By ELLIS SAMOLS AND JILL A. RYDER
}

(From the Department of Medicine, The Royal Free Hospital, London, England)

(Submitted for publication June 12, 1961 ; accepted July 10, 1961)

The radio-immunological technique for assaying endogenous plasma insulin in man recently described by Yalow and Berson $(1,2)$ promises to be of considerable value in the investigation of insulin metabolism. Other immunological methods that have been reported are not so sensitive as this method, since they fail to detect insulin in fasting normal human plasma (3). In contrast to the bioassay methods, which are limited to the estimation of "insulin-like" activity, the immunoassay is specific for insulin. The present communication describes a radio-immunological procedure for assaying endogenous (human) and exogenous (beef) insulin separately when both are present in human plasma. This differential assay is based on the observation that beef and human insulin react differently with antibeef insulin-binding antibodies in antisera from guinea pigs and man $(1,4)$. First, the plasma beef insulin level is measured with a relatively speciesspecific human antibeef insulin serum, which reacts poorly with human insulin. It is then possible to assay the plasma endogenous insulin with a guinea pig antibeef insulin serum which reacts strongly with both beef and human insulin. With this method it has been possible to demonstrate that, in man, both the liver and peripheral tissues remove endogenous and exogenous insulin from the blood.

\section{METHODS}

Hyperimmune antisera. Antibeef insulin antiserum was produced in guinea pigs by repeated weekly subcutaneous injections of Boots protamine zinc beef insulin (2). The human antibeef insulin antiserum used in this study was obtained from a diabetic patient who had always been treated with a Boots beef insulin preparation. Blood was drawn after insulin treatment had been withheld for 4 days.

\footnotetext{
* This work was supported by grants from the Medical Research Council of Great Britain and British Insulin Manufacturers.
}

Preparation of insulin- $I^{131}$. Since a minute amount of insulin- $I^{181}$ serves as a tracer in the immunological system, it is essential to use a preparation with a high specific activity so that the counting rate may be adequate. Insulin- $\mathrm{I}^{181}$ with a specific activity of 300 to $600 \mathrm{mc}$ per $\mathrm{mg}$ was obtained by the following method: 10 to $20 \mathrm{mc}$ of carrier-free, thiosulphate-free $\mathrm{I}^{131}$ (as iodide) and 100 $\mu l$ of iodine monochloride (5) are added simultaneously to 20 to $30 \mu \mathrm{g}$ of Boots crystalline beef insulin in phosphate buffer, $\mathrm{pH}$ 7.3. After shaking for 3 minutes, 20 to 50 per cent of the mixture by volume is immediately dialyzed against distilled water at $0^{\circ} \mathrm{C}$ in order to remove free $\mathrm{I}^{181}$. A variable amount of insulin- $\mathrm{I}^{181}$ is damaged by radiation; the undamaged insulin- $\mathrm{I}^{121}$ is recovered after separation from the damaged fraction on a cellulose column (2).

Assay of endogenous insulin in plasma. This assay has been described in detail by Yalow and Berson (2). Beef insulin- $\mathrm{I}^{182}$ in trace amounts is allowed to react with a suitable concentration of guinea pig antibeef insulin serum so that two-thirds to three-quarters of the beef insulin- $\mathrm{I}^{181}$ is bound to antibody. The bound insulin- $\mathrm{I}^{181}$ is separated from the free (unbound) insulin- $\mathrm{I}^{121}$ by chromatoelectrophoresis. The relative amounts of the bound and free fractions are recorded by a paper strip radioactivity scanner. Unlabeled human insulin competes with the beef insulin- $\mathrm{I}^{181}$ for binding by antibeef insulin antibody $(1,2)$ and causes a decrease in the ratio of bound insulin- $\mathrm{I}^{131} /$ free insulin- $\mathrm{I}^{121}$ (B/F ratio). The curvilinear decrease in the $B / F$ ratio as the concentration of unlabeled insulin increases permits a quantitative assay of human insulin.

A crude human insulin powder ${ }^{1}$ was used as the standard for human insulin. We have accepted Yalow and Berson's estimate of the pure insulin content of this crude preparation: 27.3 per cent pure insulin by weight or 6 $\mathrm{U}$ per mg (assuming $22 \mathrm{U}$ per $\mathrm{mg}$ for pure insulin). Recently we have found that this estimate agrees satisfactorily with our own finding of $5.61 \mathrm{U}$ per $\mathrm{mg}$ (SE, 0.58 ), using as a standard for comparison a pure human insulin. $^{2}$ These results are to be reported in full elsewhere.

All dilutions of insulin and antiserum were made in 0.1 ionic strength veronal buffer containing 0.25 per cent

\footnotetext{
1 Kindly donated by Dr. A. M. Fisher, Connaught Laboratories, Toronto, Canada, to whom we express thanks.

2 Kindly donated by Dr. P. Randle, Dept. of Biochemistry, University of Cambridge, England.
} 
human serum albumin. The human serum albumin was tested for the presence of insulin and none was detected. Standard solutions with differing amounts of human insulin contained identical concentrations of beef insulin$\mathrm{I}^{131}$ and antiserum. A standard curve is obtained by plotting the $\mathrm{B} / \mathrm{F}$ ratio as a function of the concentration of added human insulin (calculated as "pure" human insulin after correction for damaged components of insulin- $\mathrm{I}^{\text {131 }}$ ) (Figure 1).

The assay of endogenous plasma insulin was accomplished by substituting the plasma sample for the human insulin. The $B / F$ ratio given by the plasma sample is then referred to the standard curve for the corresponding insulin concentration.

Differential assay of beef and human insulin. Beef insulin reacts strongly with antibeef insulin antibodies in both guinea pig and human antisera. Human insulin reacts relatively strongly with antibeef insulin antibodies in guinea pig antisera but usually only weakly with antibodies in human antisera $(1,4,6)$. When both beef and human insulin are present in the same mixture, human antibeef insulin serum is used to measure the beef insulin content of the mixture and guinea pig antibeef insulin serum to measure the human insulin.

A standard curve showing the $B / F$ ratio plotted as a function of beef insulin concentration in human antiserum is shown in Figure 2. Compared with beef insulin, the effect of human insulin on the $B / F$ ratio is almost negligible. This is in contrast to the standard curves obtained in the guinea pig antiserum (Figure 1) which is relatively sensitive to human insulin. These standard curves are plotted after a correction has been made for damaged components of insulin- $\mathrm{I}^{\mathbf{1 3 1}}$ (2).

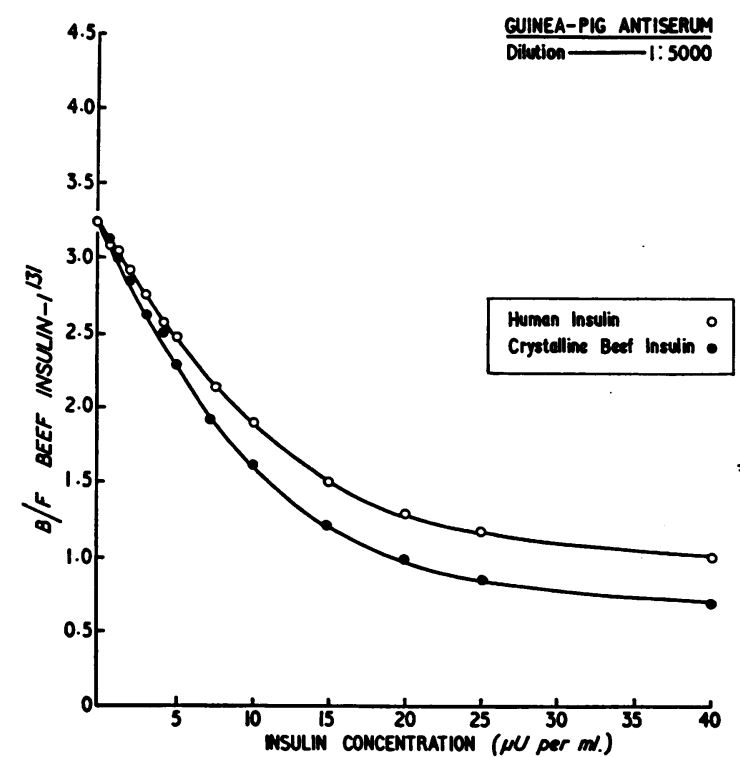

Fig. 1. Standard curves in guINEa-PIg antiserum : RATIO, BOUND INSULIN I ${ }^{181}$ /FREE INSULIN I ${ }^{181}$ (B/F RATIO) AS A FUNCTION OF THE CONCENTRATIONS OF HUMAN INSULIN OR CRYSTALLINE BEEF INSULIN.

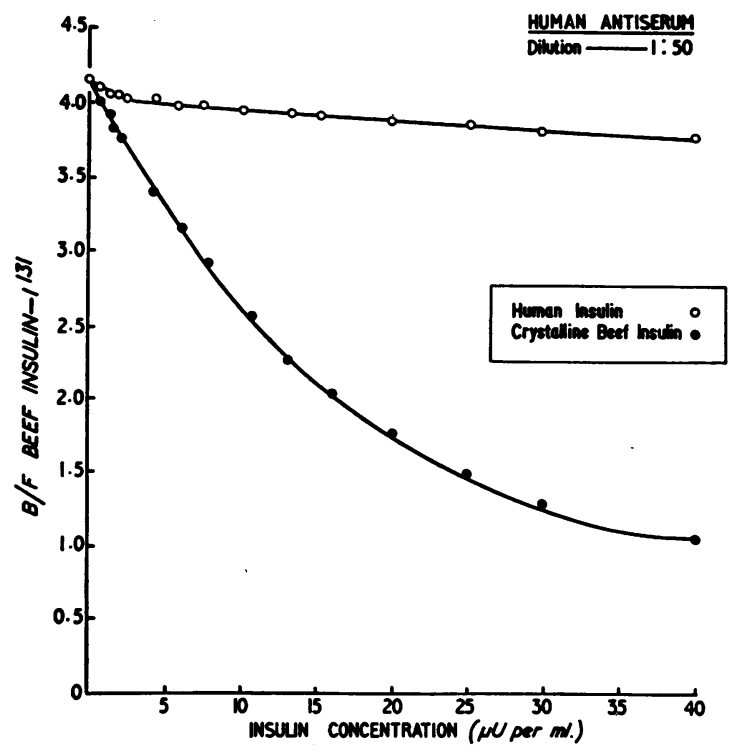

Fig. 2. Standard CURVES IN Human antiserum: B/F RATIO (BEEF INSULIN-I ${ }^{121}$ ) AS A FUNCTION OF THE CONCENTRATION OF HUMAN INSULIN OR CRYSTALLINE BEEF INSULIN.

It should be possible to repeat the standard curves with identical $\mathrm{B} / \mathrm{F}$ ratios and slopes if the same amount of radioactive insulin, unlabeled insulin and antibody are used every time. In practice, however, the adsorption of insulin to glassware and the variation in the proportion of damaged $\mathrm{I}^{131}$ after each iodination makes it difficult to ensure that the amount of tracer insulin- $\mathrm{I}^{131}$ is invariably constant. Thus, standard curves were similar but not identical, with beef insulin- $\mathrm{I}^{181}$ in a final concentration of $0.05 \mathrm{~m} \mu \mathrm{g}$ per $\mathrm{ml}$.

A mixture containing beef and human insulin is first incubated in human antiserum. The resultant $B / F$ ratio is referred to the standard curve to give the beef insulin content of the mixture. The $\mathrm{B} / \mathrm{F}$ ratio of the mixture is then determined in the guinea pig antiserum which is sensitive to both beef and human insulin. The human insulin is assayed in the guinea pig antiserum by determining the concentration of human insulin which must be added to the amount of beef insulin previously measured to give the $B / F$ ratio of the unknown mixture. It was convenient to set up tubes containing the known amount of beef insulin plus known amounts of human insulin in guinea pig antiserum at the same time as the unknown mixture. Clearly, a small error in the estimation of beef insulin may cause a large error in the assay of human insulin in a mixture containing both insulins. As the initial steep slope of the standard curve is the most sensitive index of a small change in the insulin concentration, it is preferable to dilute mixtures containing a large amount of beef insulin to obtain a suitable $\mathrm{B} / \mathrm{F}$ ratio.

Guinea pig antisera are usually less species specific than are human antisera, but the degree of species speci- 
ficity varies in different antisera, whether human or guinea pig. For the purposes of differential assay it is desirable that species specificity should be maximal in human antiserum and minimal in guinea pig antiserum. Many human and guinea pig antisera were tested, and the particular antisera used in the present investigation came closest to meeting requirements regarding species specificity.

In the absence of beef insulin, endogenous plasma insulin was assayed against the standard curve for human insulin in the guinea pig antibeef insulin system (Figure 1). All plasma samples were diluted at least 1:10 to reduce incubation damage to a minimum (2), and all mixtures were incubated at $4^{\circ} \mathrm{C}$ for 4 days.

Collection of hepatic venous, femoral arterial and femoral venous blood. In patients with end-to-side portacaval anastomoses or blocked portal veins the portal blood flow is shunted into the systemic circulation. Blood enters the liver only through the hepatic artery and leaves via the hepatic veins. The balance of insulin across the liver can then be measured directly by the difference between arterial and hepatic venous plasma insulin levels. The hepatic uptake of insulin may be calculated as the product of the arteriohepatic venous plasma insulin difference and the estimated hepatic plasma flow. Seven patients were studied. Two ( $\mathrm{Ha}$ and $\mathrm{Ki}$ ) had surgical portacaval anastomoses and cirrhosis of the liver. Two (Ar and $\mathrm{Ma}$ ) had blocked main portal veins without cirrhosis. Two (Co and Ja) had a portal collateral circulation secondary to cirrhosis or to infiltration of the liver with extramedullary hematopoeitic tissue. One patient $(\mathrm{Br})$ had ascites due to a reticulosis but had no portal collateral circulation.

All patients were fasting and sedated. Blood samples were taken from a catheter deep in the hepatic vein and an indwelling catheter in the femoral artery and vein. Hepatic blood flow was estimated at 10 -minute intervals by the clearance and extraction method of Bradley, Ingelfinger, Bradley and Currie (7), with indocyanine green as the extractable material (8). Midway between the sampling times for blood flow measurement, blood samples ( 4 to $6 \mathrm{ml}$ ) were drawn simultaneously and at a constant rate from the femoral artery and hepatic vein and, in some subjects, femoral vein. The blood was immediately placed in iced tubes containing heparin, and plasma was separated in a refrigerated centrifuge. The plasma samples were stored in a deepfreeze for insulin assay several months later.

Glucagon-free beef insulin ${ }^{3}$ was administered to 5 patients by a Sigma constant-infusion pump through an indwelling catheter in a femoral vein at a rate of 0.07 to $0.1 \mathrm{U}$ per $\mathrm{kg}$ body weight per hour. This rate of insulin infusion was chosen to produce a gradual modest decrease in in the arterial glucose concentration in order that the "counter-regulatory" responses to hypoglycemia might be kept to a minimum (9). One patient manifested the signs and symptoms of hypoglycemia during the in-

\footnotetext{
${ }^{3}$ Burroughs-Wellcome glucagon-free crystalline beef insulin.
}

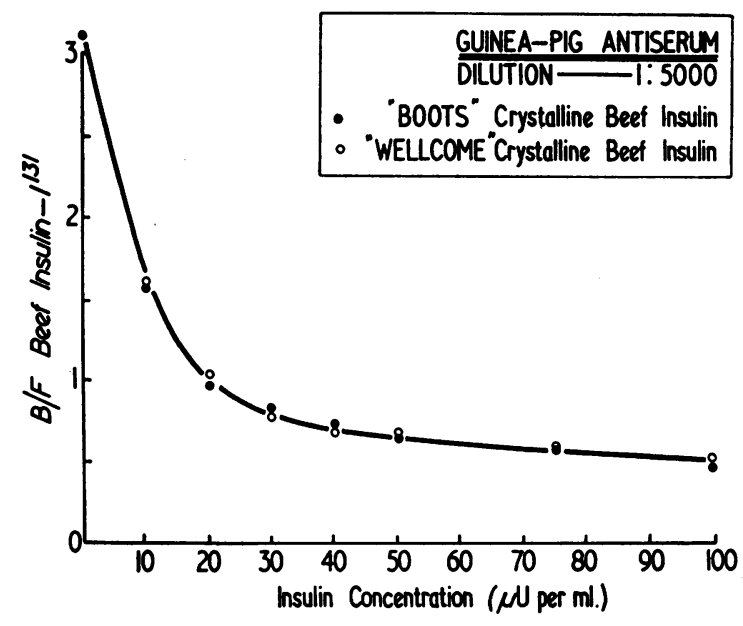

Fig. 3. B/F RATIOS OF BEEF INSULIN-I ${ }^{131}$ AS A FUNCTION OF THE CONCENTRATION OF BOOTS AND WELLCOME CRYSTALLINE BEEF INSULIN.

fusion; the others tended to be lethargic. None of the subjects had previously received insulin.

Comparison of different preparations of beef insulin. Boots 6-times recrystallized beef insulin, assayed at 22.2 $\mathrm{U}$ per $\mathrm{mg}$, was used as the routine standard for beef insulin. Since Wellcome glucagon-free crystalline beef insulin, assayed at $22.4 \mathrm{U}$ per $\mathrm{mg}$, was the insulin infused into patients, the effect was compared of the two beef insulins on the $\mathrm{B} / \mathrm{F}$ ratio for beef insulin- $\mathrm{I}^{131}$ (Figure 3). There is no significant difference between the standard curves for Boots insulin and Wellcome insulin.

\section{RESULTS}

\section{Normal fasting endogenous insulin concentra- tions}

The mean normal fasting endogenous insulin concentration of 30 normal subjects was $23 \mu \mathrm{U}$ per $\mathrm{ml}(\mathrm{SD} \pm 17.4$, range 0 to $70 \mu \mathrm{U}$ per $\mathrm{ml})$. This compares well with Yalow and Berson's mean values of $21 \mu \mathrm{U}$ per $\mathrm{ml}(\mathrm{SD} \pm 15.4$, range 0 to 66 $\mu \mathrm{U}$ per $\mathrm{ml}$ ) for a similar number of normal subjects (2).

\section{Assay of model mixtures containing known amounts of beef and human insulin}

a) No plasma present. The differential assay was applied to various combinations of beef and human insulin which had been added to the radioactive beef insulin-antiserum systems (Figure 4). The recovery of beef insulin was virtually quantitative in all of the insulin combinations tested. The recovery of human insulin, good in mixtures 


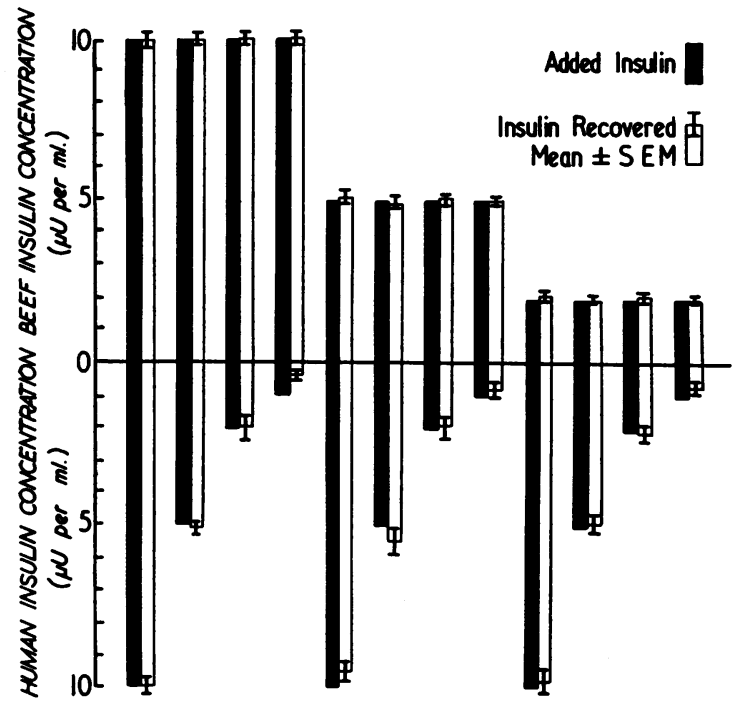

Fig. 4. ReCOVERY OF BEEF AND hUMAN INSULIN WHEN BOTH INSULINS WERE ADDED in vitro TO THE BEEF INSULIN$\mathrm{I}^{131}$-ANTISERUM SYSTEMS. Each vertical column above and below the zero line shows the concentration of beef and human insulin, respectively, in a particular mixture. Mean values for insulin recovery (unshaded columns) were derived from four replicate determinations.

containing the higher concentrations of human insulin, was less accurate when the amount of human insulin was small, particularly in the presence of the higher concentrations of beef insulin.

b) In plasma. Endogenous insulin was assayed in plasma from a normal fasting subject. The differential assay was then applied to a num-

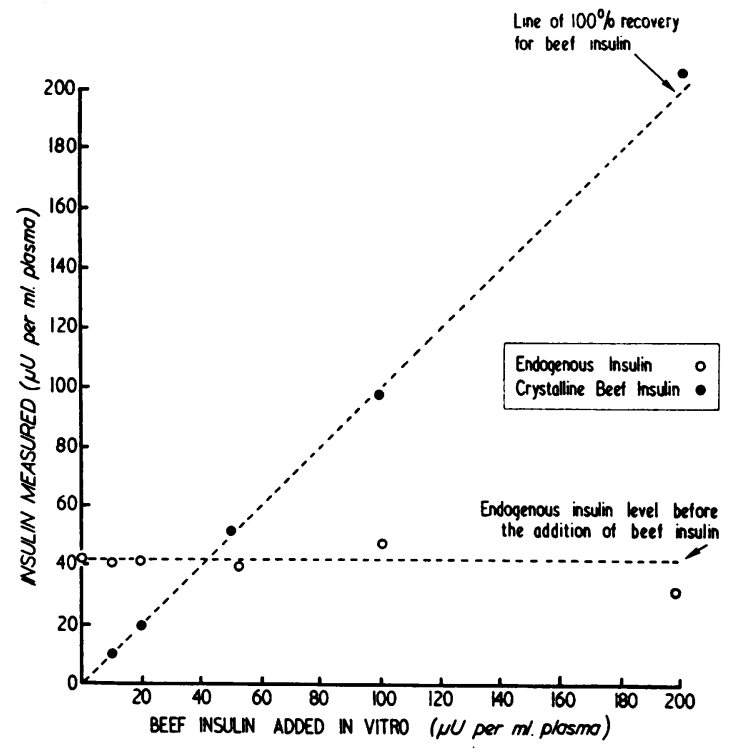

Fig. 5. Assay OF ENDOgenous INSUlin AND RECOVERY OF BEEF INSULIN AFTER ADDING BEEF INSULIN TO A FASTING PLASMa SAMPLE. The endogenous insulin concentration was $42 \mu \mathrm{U}$ per $\mathrm{ml}$ before the addition of beef insulin.

ber of aliquots of this plasma after known amounts of beef insulin had been added in vitro (Figure $5)$. The recovery of beef insulin, in concentrations varying from 10 to $200 \mu \mathrm{U}$ per ml plasma, was almost complete in the presence of an endogenous insulin content of $40 \mu \mathrm{U}$ per ml plasma. Assay of endogenous insulin in plasma containing different beef insulin concentrations yielded rea-

TABLE I

Hepatic uplake of endogenous insulin *

\begin{tabular}{|c|c|c|c|c|c|c|c|c|c|}
\hline \multirow[b]{2}{*}{ Subject } & & \multicolumn{8}{|c|}{ Time in minutes } \\
\hline & & 0 & 10 & 20 & 30 & 40 & 50 & 60 & Mean \\
\hline $\begin{array}{l}\text { Ha, } 42 \text { years; } \\
80 \mathrm{~kg} ; \\
\text { portacaval } \\
\text { anastomosis; } \\
\text { cirrhosis }\end{array}$ & $\begin{array}{l}\mathrm{A} \\
\mathrm{HV} \\
\mathrm{A}-\mathrm{HV} \\
(\mathrm{A}-\mathrm{HV}) / \mathrm{A} \\
\mathrm{EHPF}\end{array}$ & $\begin{array}{l}37 \\
16 \\
21 \\
0.57\end{array}$ & $\begin{array}{l}34 \\
16 \\
18 \\
0.53\end{array}$ & $\begin{array}{c}26 \\
14 \\
12 \\
0.46 \\
400\end{array}$ & $\begin{array}{c}21 \\
10 \\
11 \\
0.52 \\
400\end{array}$ & $\begin{array}{c}28 \\
14 \\
14 \\
0.50 \\
470\end{array}$ & $\begin{array}{l}24 \\
14 \\
8 \\
0.33 \\
540\end{array}$ & $\begin{array}{c}18 \\
13 \\
5 \\
0.28 \\
560\end{array}$ & 0.46 \\
\hline $\begin{array}{l}\text { Ar, } 60 \text { years; } \\
48 \mathrm{~kg} \text {; } \\
\text { extrahepatic } \\
\text { portal block; } \\
\text { liver normal }\end{array}$ & $\begin{array}{l}\text { HIU per kg } \\
\text { A } \\
\text { HV } \\
\text { A - HV } \\
(\mathrm{A}-\mathrm{HV}) / \mathrm{A} \\
\text { EHPF } \\
\text { HIU per kg }\end{array}$ & $\begin{array}{l}22 \\
16 \\
6 \\
0.27\end{array}$ & $\begin{array}{c}22 \\
17 \\
5 \\
0.23 \\
580 \\
60.4\end{array}$ & $\begin{array}{l}60.0 \\
24 \\
21 \\
3 \\
0.12 \\
580 \\
36.2\end{array}$ & $\begin{array}{c}55.0 \\
22 \\
18 \\
4 \\
0.18 \\
578 \\
48.2\end{array}$ & $\begin{array}{l}82.2 \\
24 \\
20 \\
4 \\
0.17 \\
623 \\
51.9\end{array}$ & $\begin{array}{l}54.0 \\
26 \\
22 \\
4 \\
0.15 \\
645 \\
53.8\end{array}$ & 35.0 & $\begin{array}{r}0.19 \\
50.1\end{array}$ \\
\hline
\end{tabular}

* $\mathrm{A}=$ arterial plasma insulin concentration in $\mu \mathrm{U}$ per $\mathrm{ml} ; \mathrm{HV}=$ hepatic venous plasma insulin concentration in $\mu \mathrm{U}$ per $\mathrm{ml} ; \mathrm{A}-\mathrm{HV}=$ arterial minus hepatic venous insulin concentration in $\mu \mathrm{U}$ per $\mathrm{ml} ;(\mathrm{A}-\mathrm{HV}) / \mathrm{A}=$ arterial minus hepatic venous insulin concentration divided by arterial insulin concentration; EHPF = estimated hepatic plasma flow in $\mathrm{ml}$ per minute; $\mathrm{HIU}=$ hepatic insulin uptake in $\mu \mathrm{U}$ per minute per $\mathrm{kg}$ body weight. 
sonably consistent results. The endogenous and beef insulin concentrations in this model are representative of the plasma levels in the subjects in our study before and after beef insulin infusion.

\section{Hepatic uptake of endogenous insulin}

a) In the absence of insulin infusion. There was a significant arteriohepatic venous difference in endogenous insulin levels in all four subjects ( $\mathrm{Ki}, \mathrm{Ma}, \mathrm{Ha}, \mathrm{Ar}$ ) who had either portacaval anastomoses or portal vein thromboses (Tables I and II). The clearance of insulin by the liver in a single trans-hepatic passage was shown by the ratio: (arteriohepatic venous difference/arterial plasma insulin concentration) [(A-HV)/A]. The hepatic endogenous insulin uptake per kilogram body weight (HIU) in these four patients was calculated as the product of the arteriohepatic venous plasma insulin difference and the estimated hepatic blood flow and expressed as microunits per minute per kilogram body weight (Tables I and II). The endogenous insulin $(\mathrm{A}-\mathrm{HV}) / \mathrm{A}$ ratio was determined for each batch of plasma samples collected every 10 minutes (Tables I and II). The mean $(\mathrm{A}-\mathrm{HV}) / \mathrm{A}$ ratio for endogenous insulin was 0.46 in Subject $\mathrm{Ha}$ (over 60

TABLE II

Hepatic uptake of insulin before and during the slow infusion of beef insulin*

\begin{tabular}{|c|c|c|c|c|c|c|c|c|c|c|c|}
\hline \multirow[b]{2}{*}{ Subject } & \multirow[b]{2}{*}{ Minutes: } & \multicolumn{3}{|c|}{ Preinfusion values } & \multirow[b]{2}{*}{ Mean } & \multicolumn{5}{|c|}{ Time during beef insulin infusion } & \multirow[b]{2}{*}{ Mean } \\
\hline & & -20 & -10 & $\mathbf{0}$ & & 10 & 20 & 30 & 40 & 50 & \\
\hline \multicolumn{6}{|c|}{ A. Complete portal-systemic shunt } & \multicolumn{5}{|c|}{$0.10 \mathrm{U} / \mathrm{kg} / \mathrm{hr}$} & \\
\hline \multirow{8}{*}{$\begin{array}{l}\mathrm{Ki}, 45 \text { years; } \\
60.1 \mathrm{~kg} ; \\
\text { portacaval } \\
\text { anastomosis; } \\
\text { cirrhosis }\end{array}$} & $\begin{array}{l}\text { A endog. } \\
\text { exog. }\end{array}$ & 13 & 15 & 14 & & $\begin{array}{l}15 \\
87\end{array}$ & $\begin{array}{r}12 \\
161\end{array}$ & $\begin{array}{r}10 \\
214\end{array}$ & $\begin{array}{r}10 \\
246\end{array}$ & & \\
\hline & $\begin{array}{l}\text { HV endog. } \\
\text { exog. }\end{array}$ & 8 & 8 & 6 & & $\begin{array}{r}5 \\
62\end{array}$ & $\begin{array}{r}5 \\
97\end{array}$ & $\begin{array}{r}5 \\
105\end{array}$ & $\begin{array}{r}2 \\
128\end{array}$ & & \\
\hline & $\begin{array}{c}\text { A - HV endog. } \\
\text { exog. }\end{array}$ & 5 & 7 & 8 & & $\begin{array}{l}10 \\
25\end{array}$ & $\begin{array}{r}7 \\
72\end{array}$ & $\begin{array}{r}5 \\
109\end{array}$ & $\begin{array}{r}8 \\
118\end{array}$ & & \\
\hline & $\begin{array}{c}(\mathrm{A}-\mathrm{HV}) / \mathrm{A} \text { endog. } \\
\text { exog. }\end{array}$ & 0.38 & 0.47 & 0.57 & 0.47 & $\begin{array}{l}0.33 \\
0.29\end{array}$ & $\begin{array}{l}0.42 \\
0.43\end{array}$ & $\begin{array}{l}0.50 \\
0.51\end{array}$ & $\begin{array}{l}0.80 \\
0.49\end{array}$ & & $\begin{array}{l}0.51 \\
0.42\end{array}$ \\
\hline & EHPF & & & 259 & & 271 & 272 & 258 & 295 & & \\
\hline & HIU endog. & & & 34.5 & & 45.1 & 31.7 & 21.5 & 29.5 & & 32.0 \\
\hline & $\begin{array}{l}\text { Per kg } \\
\quad \text { exog. }\end{array}$ & & & & & 112.7 & 325.8 & 467. 9 & 579.2 & & \\
\hline & & & & & & \multicolumn{5}{|c|}{$0.10 \mathrm{U} / \mathrm{kg} / \mathrm{hr}$} & \\
\hline \multirow{7}{*}{$\begin{array}{l}\text { Ma, } 45 \text { years; } \\
80 \text { kg; } \\
\text { extrahepatic } \\
\text { portal block; } \\
\text { myeloid leu- } \\
\text { kemia }\end{array}$} & $\begin{array}{l}\text { A endog. } \\
\text { exog. }\end{array}$ & 38 & 45 & 39 & & $\begin{array}{l}40 \\
85\end{array}$ & $\begin{array}{r}33 \\
152\end{array}$ & $\begin{array}{r}28 \\
202\end{array}$ & $\begin{array}{r}21 \\
231\end{array}$ & $\begin{array}{r}21 \\
251\end{array}$ & \\
\hline & $\begin{array}{l}\text { HV endog. } \\
\text { exog. }\end{array}$ & 23 & 26 & 23 & & $\begin{array}{l}28 \\
46\end{array}$ & $\begin{array}{c}19 \\
91\end{array}$ & $\begin{array}{r}20 \\
112\end{array}$ & $\begin{array}{r}12 \\
130\end{array}$ & $\begin{array}{r}14 \\
145\end{array}$ & \\
\hline & $\begin{array}{c}\text { A - HV endog. } \\
\text { exog. }\end{array}$ & 15 & 19 & 16 & & $\begin{array}{l}12 \\
39\end{array}$ & $\begin{array}{l}14 \\
61\end{array}$ & $\begin{array}{r}8 \\
90\end{array}$ & $\begin{array}{r}9 \\
101\end{array}$ & 106 & \\
\hline & $\begin{array}{c}\text { A - HV/A endog. } \\
\text { exog. }\end{array}$ & 0.40 & 0.42 & 0.41 & 0.41 & $\begin{array}{l}0.30 \\
0.46\end{array}$ & $\begin{array}{l}0.42 \\
0.40\end{array}$ & $\begin{array}{l}0.29 \\
0.44\end{array}$ & $\begin{array}{l}0.43 \\
0.43\end{array}$ & $\begin{array}{l}0.33 \\
0.42\end{array}$ & $\begin{array}{l}0.36 \\
0.43\end{array}$ \\
\hline & EHPF & & & 820 & & 820 & 820 & 820 & 820 & 820 & \\
\hline & HIU endog. & & & 164.0 & & 123.0 & 143.5 & 82.0 & 92.2 & 61.5 & 100.4 \\
\hline & exog. & & & & & 399.8 & 625.2 & 922.5 & $1,035.2$ & $1,086.5$ & \\
\hline \multicolumn{5}{|c|}{ B. Partial portal-systemic shunt } & & \multicolumn{5}{|c|}{$0.10 \mathrm{U} / \mathrm{kg} / \mathrm{hr}$} & \\
\hline \multirow{3}{*}{$\begin{array}{l}\text { Co, } 60 \text { years; } \\
60 \mathrm{~kg} ; \\
\text { myelosclerosis }\end{array}$} & $\begin{array}{l}\text { A endog. } \\
\text { exog. }\end{array}$ & 48 & 49 & 46 & & $\begin{array}{l}30 \\
74\end{array}$ & $\begin{array}{r}10 \\
149\end{array}$ & $\begin{array}{r}0 \\
198\end{array}$ & $\begin{array}{r}0 \\
246\end{array}$ & $\begin{array}{r}0 \\
281\end{array}$ & \\
\hline & $\begin{array}{l}\text { HV endog. } \\
\text { exog. }\end{array}$ & 56 & 54 & 50 & & $\begin{array}{l}30 \\
47\end{array}$ & $\begin{array}{l}16 \\
85\end{array}$ & $\begin{array}{r}0 \\
152\end{array}$ & $\begin{array}{r}0 \\
183\end{array}$ & $\begin{array}{r}0 \\
209\end{array}$ & \\
\hline & & & & & & \multicolumn{5}{|c|}{$0.07 \mathrm{U} / \mathrm{kg} / \mathrm{hr}$} & \\
\hline \multirow{2}{*}{$\begin{array}{l}\mathrm{Ja}, 42 \text { years; } \\
50 \mathrm{~kg} ; \\
\text { cirrhosis }\end{array}$} & $\begin{array}{l}\text { A endog. } \\
\text { exog. }\end{array}$ & 8 & 7 & 8 & & $\begin{array}{r}5 \\
88\end{array}$ & $\begin{array}{r}5 \\
157\end{array}$ & $\begin{array}{r}0 \\
221\end{array}$ & $\begin{array}{r}0 \\
253\end{array}$ & $\begin{array}{r}0 \\
262\end{array}$ & \\
\hline & $\begin{array}{l}\text { HV endog. } \\
\text { exog. }\end{array}$ & 18 & 12 & 12 & & $\begin{array}{l}15 \\
59\end{array}$ & $\begin{array}{r}12 \\
109\end{array}$ & $\begin{array}{r}5 \\
165\end{array}$ & $\begin{array}{r}0 \\
208\end{array}$ & $\begin{array}{r}0 \\
212\end{array}$ & \\
\hline \multicolumn{5}{|c|}{ C. No portal-systemic shunt } & & \multicolumn{5}{|c|}{$0.10 \mathrm{U} / \mathrm{kg} / \mathrm{hr}$} & \\
\hline \multirow{2}{*}{$\begin{array}{l}\mathrm{Br}, 50 \text { years; } \\
80 \mathrm{~kg} \\
\text { reticulosis }\end{array}$} & $\begin{array}{l}\text { A endog. } \\
\text { exog. }\end{array}$ & 18 & 11 & 14 & & $\begin{array}{l}18 \\
58\end{array}$ & $\begin{array}{l}16 \\
96\end{array}$ & $\begin{array}{r}13 \\
152\end{array}$ & $\begin{array}{r}12 \\
192\end{array}$ & & \\
\hline & $\begin{array}{l}\text { HV endog. } \\
\text { exog. }\end{array}$ & 35 & 32 & 35 & & 38 & 29 & 31 & 26 & & \\
\hline
\end{tabular}

* Endog. =endogenous (human) insulin; exog. =exogenous (beef) insulin. See Table I for other abbreviations. 
minutes) and 0.19 in Subject Ar (over 50 minutes), and in Subjects $\mathrm{Ki}$ and $\mathrm{Ma}$ over $30 \mathrm{~min}$ utes the ratios were 0.47 and 0.41 , respectively. The average endogenous insulin $(\mathrm{A}-\mathrm{HV}) / \mathrm{A}$ ratio of 19 different determinations in the four patients $(\mathrm{Ki}, \mathrm{Ma}, \mathrm{Ha}, \mathrm{Ar})$ was 0.41 . The mean endogenous HIU during a 50-minute period was $57 \mu \mathrm{U}$ per minute per $\mathrm{kg}$ in Subject $\mathrm{Ha}$ and 50 $\mu \mathrm{U}$ in Subject Ar. In Subjects $\mathrm{Ki}$ and $\mathrm{Ma}$ the $\mathrm{HIU}$ values were 34 and $164 \mu \mathrm{U}$ per minute per $\mathrm{kg}$, respectively.

b) During insulin infusion. A hepatic uptake of endogenous insulin was still apparent during the infusion of beef insulin. The mean (A $\mathrm{HV}$ )/A ratio for endogenous insulin was 0.51 in Subject $\mathrm{Ki}$, with a HIU of $32 \mu \mathrm{U}$ per minute per $\mathrm{kg}$ during a 40 -minute infusion, and 0.36 in Subject $\mathrm{Ma}$, with a $\mathrm{HIU}$ of $100 \mu \mathrm{U}$ per minute per $\mathrm{kg}$ during a 50-minute infusion (Table II). The similarity of these ratios and HIU values to the respective preinfusion values suggests that the proportion of endogenous insulin cleared by the liver was not affected by the presence of exogenous insulin.

Of the three patients who had patent portal veins, Co and Ja had a collateral portal systemic circulation, but portal blood was flowing through the liver. All three patients showed higher levels of endogenous insulin in the hepatic venous samples than in arterial samples, both before and during insulin infusion.

\section{Hepatic uptake of exogenous insulin}

This may be compared with that for endogenous insulin in Table II. The $(\mathrm{A}-\mathrm{HV}) / \mathrm{A}$ ratios for endogenous insulin before and during the beef insulin infusion were remarkably similar to those for exogenous insulin in Patients $\mathrm{Ma}$ and $\mathrm{Ki}$. The mean $(\mathrm{A}-\mathrm{HV}) / \mathrm{A}$ ratio for exogenous insulin was 0.42 in both $\mathrm{Ma}$ (4 determinations) and $\mathrm{Ki}$ (5 determinations). The $(\mathrm{A}-\mathrm{HV}) / \mathrm{A}$ ratio did not change significantly with rising arterial plasma insulin levels, nor was there any appreciable variation in estimated hepatic plasma flow. Thus, it appears that insulin was removed by the liver according to the law of a first-order reaction. The mechanism governing hepatic insulin capture was not saturated by arterial plasma insulin concentrations exceeding $250 \mu \mathrm{U}$ per $\mathrm{ml}$. While the
TABLE III

Balance of endogenous insulin across the periphery; Subject $\mathrm{Ha}^{*}$

\begin{tabular}{lccccccc}
\hline \hline & \multicolumn{7}{c}{ Time in minutes } \\
\cline { 2 - 8 } & 0 & 10 & 20 & 30 & 40 & 50 & 60 \\
\hline A & 37 & 34 & 26 & 21 & 28 & 24 & 18 \\
FV & 30 & 29 & 20 & 16 & 22 & 20 & 16 \\
A - FV & 7 & 5 & 6 & 5 & 6 & 4 & 2 \\
$(\mathrm{~A}-\mathrm{FV}) / \mathrm{A}$ & 0.19 & 0.15 & 0.23 & 0.24 & 0.21 & 0.17 & 0.11 \\
\hline
\end{tabular}

* $\mathrm{A}=$ arterial plasma insulin concentration in $\mu \mathrm{U}$ per $\mathrm{ml} ; \mathrm{FV}=$ femoral venous plasma insulin concentration in $\mu \mathrm{U}$ per $\mathrm{ml} ; \mathrm{A}-\mathrm{FV}=$ arterial minus femoral venous insulin concentration in $\mu \mathrm{U}$ per $\mathrm{ml} ;(\mathrm{A}-\mathrm{FV}) / \mathrm{A}=$ arterial minus femoral venous insulin concentration divided by arterial insulin concentration.

hepatic insulin uptake cannot be calculated in the patients with intact portal veins, it is apparent that in these patients a significant amount of exogenous insulin was also removed from the splanchnic circulation (Table II) by the liver.

\section{Peripheral insulin uptake}

A definite femoral arteriovenous difference for both endogenous and exogenous insulin is shown in Tables III and IV. Only beef insulin was measured in plasma collected during the infusion. The peripheral $(\mathrm{A}-\mathrm{HV}) / \mathrm{A}$ ratio, which reflects the insulin uptake of the whole leg, comprising a number of different tissues, was much more variable than the $(\mathrm{A}-\mathrm{HV}) / \mathrm{A}$ ratio across the liver, which was also larger.

\section{Velocity constant of elimination of exogenous insulin}

The mean increase in arterial plasma total (endogenous plus exogenous) insulin concentration in seven patients during 50 minutes of beef insulin infusion is shown in Figure 6. The mean preinfusion arterial plasma endogenous insulin concentration was $25 \mu \mathrm{U}$ per ml. It was not feasible to continue the beef insulin infusion for a longer period in an attempt to reach the steady state. Assumed that the elimination of the infused insulin from arterial plasma proceeds as a first-order reaction, sufficient data are available to estimate a hypothetical equilibrium concentration of plasma insulin (see Appendix); tentative values for the velocity constant of elimination, $k$, and the mean volume of distribution, $v$, could then be computed. The mean velocity constant of elimination, $k$, was 0.02 minute $^{-1}$ and the mean volume of distribu- 
TABLE IV

Peripheral uptake of insulin before and during the slow infusion of beef insulin *

\begin{tabular}{|c|c|c|c|c|c|c|c|c|c|}
\hline \multirow[b]{2}{*}{ Subjects } & \multirow[b]{2}{*}{ Minutes: } & \multicolumn{3}{|c|}{$\begin{array}{l}\text { Endogenous insulin, } \\
\text { preinfusion values }\end{array}$} & \multicolumn{5}{|c|}{ Beef insulin values during infusion } \\
\hline & & -20 & -10 & $\mathbf{0}$ & 10 & 20 & 30 & 40 & 50 \\
\hline $\mathrm{Ki}$ & $\begin{array}{l}A \\
F V \\
A-F V \\
(A-F V) / A\end{array}$ & $\begin{array}{l}13 \\
11 \\
2 \\
0.15\end{array}$ & $\begin{array}{l}15 \\
12 \\
3 \\
0.20\end{array}$ & $\begin{array}{l}14 \\
10 \\
4 \\
0.28\end{array}$ & $\begin{array}{l}87 \\
81 \\
6 \\
0.07\end{array}$ & $\begin{array}{l}169 \\
161 \\
\quad 8 \\
0.05\end{array}$ & $\begin{array}{c}214 \\
188 \\
26 \\
0.12\end{array}$ & $\begin{array}{l}246 \\
202 \\
34 \\
0.14\end{array}$ & \\
\hline $\mathrm{Ma}$ & $\begin{array}{l}A \\
F V \\
A-F V \\
(A-F V) / A\end{array}$ & $\begin{array}{c}38 \\
36 \\
2 \\
0.05\end{array}$ & $\begin{array}{l}45 \\
38 \\
7 \\
0.16\end{array}$ & $\begin{array}{l}39 \\
30 \\
9 \\
0.23\end{array}$ & $\begin{array}{l}85 \\
79 \\
6 \\
0.07\end{array}$ & $\begin{array}{c}152 \\
136 \\
16 \\
0.10\end{array}$ & $\begin{array}{l}202 \\
180 \\
22 \\
0.11\end{array}$ & $\begin{array}{c}231 \\
218 \\
13 \\
0.06\end{array}$ & $\begin{array}{l}251 \\
233 \\
18 \\
0.07\end{array}$ \\
\hline $\mathrm{Br}$ & $\begin{array}{l}A \\
F V \\
A-F V \\
(A-F V) / A\end{array}$ & $\begin{array}{l}18 \\
14 \\
4 \\
0.22\end{array}$ & $\begin{array}{l}11 \\
8 \\
3 \\
0.27\end{array}$ & $\begin{array}{l}14 \\
9 \\
5 \\
0.36\end{array}$ & $\begin{array}{l}58 \\
51 \\
7 \\
0.12\end{array}$ & $\begin{array}{l}96 \\
89 \\
7 \\
0.07\end{array}$ & $\begin{array}{c}152 \\
128 \\
24 \\
.0 .16\end{array}$ & $\begin{array}{c}192 \\
177 \\
15 \\
0.08\end{array}$ & \\
\hline Mean & $\begin{array}{l}A \\
F V \\
A-F V \\
(A-F V) / A\end{array}$ & $\begin{array}{l}23 \\
20 \\
3 \\
0.13\end{array}$ & $\begin{array}{l}24 \\
19 \\
5 \\
0.21\end{array}$ & $\begin{array}{l}22 \\
16 \\
6 \\
0.27\end{array}$ & $\begin{array}{l}77 \\
70 \\
7 \\
0.09\end{array}$ & $\begin{array}{c}139 \\
129 \\
10 \\
0.07\end{array}$ & $\begin{array}{c}189 \\
165 \\
24 \\
0.13\end{array}$ & $\begin{array}{l}223 \\
199 \\
24 \\
0.11\end{array}$ & \\
\hline Over-all mean & $(A-F V) / A$ & & 0.20 & & & & 0.10 & & \\
\hline
\end{tabular}

* See Table III for abbreviations.

tion, $v$, was $13 \mathrm{~L}$, or 20 per cent of the mean body weight.

\section{Effect of oxygenation and deoxygenation of whole blood}

It is reported that oxygenation of blood either in the lungs or in vitro can lead to a rise in the

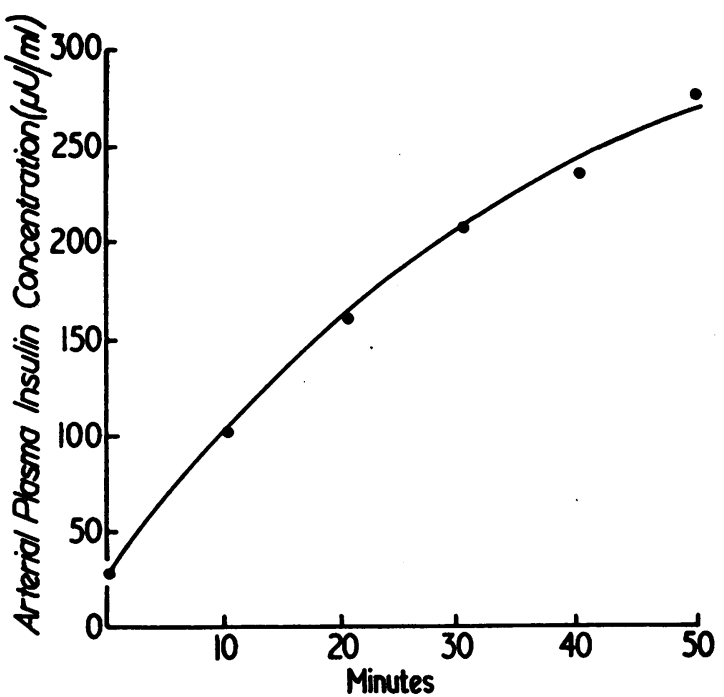

Fig. 6. Mean RISE IN ARTERIAL PLASMa total INSULIN CONCENTRATION DURING THE INFUSION OF BEEF INSULIN. The mean arterial plasma endogenous insulin concentration before infusion was $25 \mu \mathrm{U}$ per $\mathrm{ml}$.

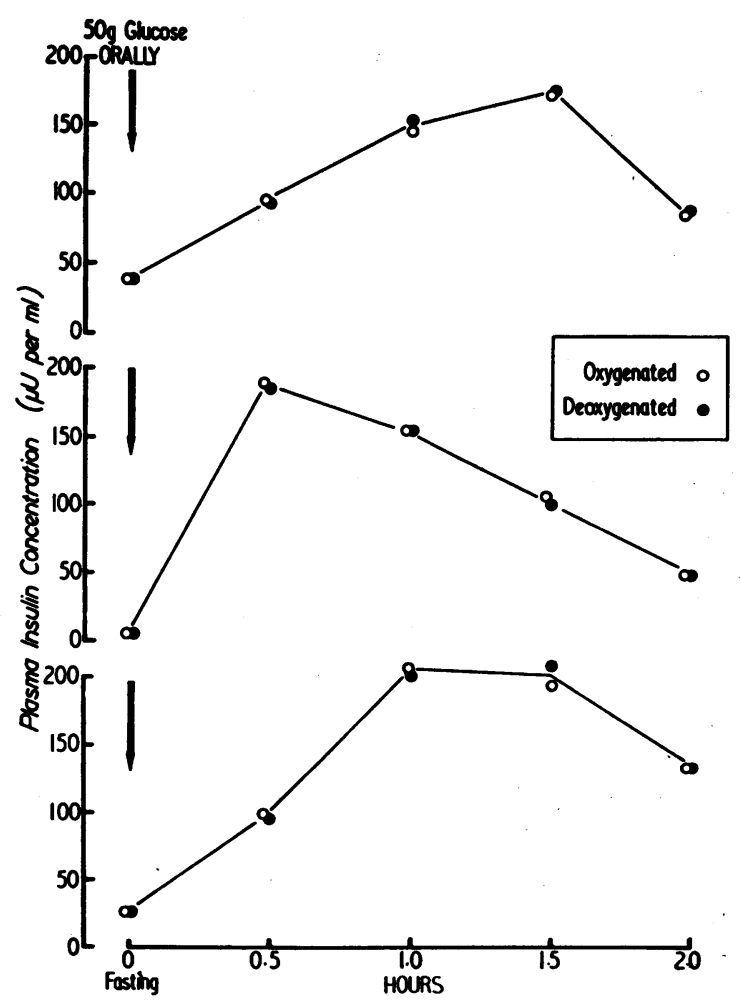

Fig. 7. Plasma endogenous insulin concentrations AFTER in vitro OXYGENATION AND DEOXYGENATION OF VENOUS WHOLE BLOOD. Taken during a glucose tolerance test in 3 normal subjects; each symbol represents the mean of duplicate determinations. 
biologically estimated endogenous insulin-like activity $(10,11)$. A similar effect on the immunoassay would give rise to spurious arteriovenous differences in insulin levels. A wide range of endogenous insulin levels was obtained by drawing venous blood during a glucose tolerance test in three normal subjects. Plasma was immediately separated after in vitro oxygenation and deoxygenation of aliquots of whole blood (11). Immunoassay of plasma separated from the same sample of blood after oxygenation and deoxygenation showed no significant difference in the levels of endogenous insulin (Figure 7). Thus, arteriovenous differences in insulin concentration demonstrated by immunoassay could not be ascribed to the influence of oxygenation and deoxygenation.

\section{DISCUSSION}

Biological methods that measure "insulin-like" activity in plasma have given widely differing estimates of the normal range for the fasting plasma insulin concentration (12-18). Yalow and Berson have pointed out that the plasma insulin levels obtained by their immunoassay technique are in agreement with the lowest of these estimates (2). The fasting venous endogenous insulin concentrations in this study accord well with the findings of Yalow and Berson in normal subjects and cirrhotic patients, confirming the reproducibility and consistency of the radio-immunoassay technique.

The differential assay of endogenous and exogenous insulin when both are present in the same plasma is based upon the marked differences in species specificity that can be found in guinea pig and human antibeef insulin antisera. The differential assay provides a sensitive and precise measurement of beef insulin, independent of the concentration of human insulin in the insulin mixture. The measurement of human insulin. primarily dependent upon the complete recovery of beef insulin, is reliable at most concentrations of human insulin, but accuracy may be impaired in a mixture combining a very low human insulin content with a high beef insulin concentration. It has been suggested that differences and similarities in the binding of various animal insulins with antibodies in human antibeef-pork insulin sera may be due to differences in the amino acid sequence of residues 8 to 10 of the A-chain (4).
We have no adequate explanation for the variations in species specificity shown by human or by guinea pig antibeef insulin sera. It should be noted that insulin preparations made by British manufacturers contain only beef insulin. In our experience different human antibeef insulin antisera have shown a wide range of species specificity for human and beef insulins. The degree of species specificity is, however, constant and reproducible for any particular antiserum using trace concentrations of insulin- $\mathrm{I}^{131}$. Grodsky and Forsham recently reported minor or less than 3 -fold differences in the binding of human and beef insulin in human antibeef-pork antisera (19), in contrast to the 25- to 100-fold differences described by Berson and Yalow $(4,6)$. This apparent discrepancy could be related to the variations in species specificity in different human antisera, or could be due to differences in technique. Cross reactions between animal insulins have been demonstrated in other immunological systems by $\mathrm{Ar}$ quilla and Stavitsky (3) with the red cell hemagglutination-inhibition technique.

The potential application of the procedure described for assaying beef and human insulin, when both are present in plasma, may have limitations. Its use might be confined to patients who are receiving exogenous insulin for the first time or who have been treated with insulin for only a short while and have not developed antibodies to insulin. While it is possible to dilute insulintreated diabetic plasma containing insulin-binding antibodies so that these have little effect in vitro, the reaction of insulin-binding antibodies with endogenous insulin in vivo and the effects of these antibodies on endogenous insulin degradation and distribution may invalidate the differential assay described.

It has been suggested that in vitro biological methods cannot be used to measure arteriovenous differences in insulin-like activity. The insulinlike activity of the blood in the venous drainage to the pancreas, measured by the rat diaphragm or the rat adipose tissue method, is less than that in simultaneously sampled arterial blood; and oxygenation of blood either in the lungs or in vitro can lead to a rise in the biologically estimated insulin-like activity $(10,11)$. It is unlikely that the arteriovenous differences in insulin concentration demonstrated by immunoassay could be ascribed to 
the influence of oxygenation and deoxygenation. No significant difference has been found in the plasma insulin concentration of the blood after oxygenation and deoxygenation in vitro. The patients with intact portal veins showed a higher insulin concentration in hepatic venous plasma than in arterial plasma.

The results of this investigation show that, in man, the liver is capable of removing 20 to 50 per cent of the insulin passing through it for periods of over 1 hour. Mortimore and Tietze (20) found that about 40 per cent of insulin- $\mathrm{I}^{131}$ entering an isolated, cyclically perfused rat liver, was removed in a single trans-hepatic circulation. Madison, Combes, Unger and Kaplan compared the volume of distribution of insulin after a rapid injection into the portal vein (21) and calculated that more than 50 per cent of the insulin- ${ }^{131}$ was bound to the liver in a single trans-hepatic circulation.

Little is known about the mechanism of capture of insulin by the liver. While it appears from our results that the hepatic uptake of insulin is a first-order reaction, there was no evidence of saturation of the sites of hepatic removal by the high level of insulin toward the end of the beef insulin infusion.

The proportion of insulin taken up by the liver before and during insulin infusion remained relatively constant in our patients. This may indicate that hepatic uptake was maximal throughout, with the arterial insulin concentration as the ratelimiting factor, but it should be noted that certain aspects in this investigation were distinctly not physiological: the physiological secretion of insulin is evoked by hyperglycemia, which was not present; a portal systemic shunt or liver disease was present in most of the patients investigated, and could result in findings that might not occur in healthy subjects. In spite of these considerations the radio-immunoassay method has demonstrated a hepatic and peripheral uptake of insulin in man. This technique may be a valuable means for investigating endogenous or exogenous insulin uptake by various tissues in patients with disorders of carbohydrate metabolism. Such a study might test whether some diabetics have defects in peripheral or hepatic metabolism of insulin. In some diabetics an abnormal insulin might be present that reacts well immunologically but poorly as a hormone in vivo. Immunoassay has already shown that absolute insulin deficiency is not the cause of hyperglycemia in early maturity onset diabetics $(2,22)$ and at least in some juvenile diabetics (22).

The present estimations of mean velocity constant of elimination and mean volume of distribution of insulin are based upon two theoretical considerations: 1) the assumption that the infused insulin is eliminated as a first-order reaction, and 2) formulae that have been constructed to express the elimination of a substance according to firstorder kinetics during a constant intravenous infusion. Similar mathematical treatment has been used to estimate the velocity constant of elimination $(k)$ and the volume of distribution $(v)$ of glucose (23) and vasopressin (24) administered by constant intravenous infusion until a steady state supervened. The assumptions in the mathematical analysis are not free from objections (see Appendix). The meaning of the concept of a volume of distribution, $v$, as determined during a constant intravenous infusion, is complicated when a comparison is made with the method for obtaining $v$ after a single intravenous injection of a substance. After a single injection, $v$ is dependent upon the hypothetical concentration that would exist immediately after the injection if the steady state of infusion were reached at once, by extrapolation from the logarithmically linear part of the disappearance curve, ignoring the initial high concentration after the injection.

It has previously been shown that after a single intravenous injection of insulin- $\mathrm{I}^{131}$ in amounts ranging from 0.1 to $7.0 \mathrm{U}$, the degradation reaction follows first-order kinetics (25). The mean velocity constant of elimination, $k$, was $0.02 \mathrm{~min}$ ute $^{-1}$ and the mean apparent volume of distribution, $v$, was 37 per cent of body weight in about 45 minutes, distribution being about half completed at 15 minutes. These data are thus not comparable with the $k$ value in the present study which is numerically equal $\left(0.02\right.$ minute $\left.^{-1}\right)$ and a $v$ value of 20 per cent of the mean body weight, since these values are derived from constant intravenous infusion data.

\section{SUM MARY}

1. Immunoassay of plasma insulin in man, as devised by Yalow and Berson, is confirmed to be 
a highly sensitive method for insulin assay, yielding consistent and reproducible results. Normal fasting endogenous plasma insulin concentrations did not exceed $70 \mu \mathrm{U}$ per $\mathrm{ml}$.

2. A sensitive differential immunoassay is presented for measuring separately beef and human insulin in plasma in man after beef insulin administration. This assay is based upon differences in species specificity shown by human and guinea pig antibeef insulin antisera.

3. Immunoassay, in contrast to the rat adipose tissue or diaphragm methods, is not influenced by oxygenation or deoxygenation of whole blood in vitro or in vivo. This procedure may therefore be used to measure arteriovenous differences in insulin concentration.

4. A significant hepatic uptake of endogenous insulin is demonstrated in four patients with portacaval anastomoses or extrahepatic portal blocks. Sampling of arterial and hepatovenous blood and estimation of hepatic blood flow permits the calculation of the balance of insulin across the liver. The mean proportion of arterial insulin removed by the liver, reflected by the ratio: (arteriohepatic venous difference in insulin concentration/arterial insulin concentration) $[(\mathrm{A}-\mathrm{HV}) / \mathrm{A}]$ was similar for endogenous (mean, 0.40 ) and exogenous (mean, 0.42 ) insulin. The hepatic uptake of endogenous insulin in each patient was relatively constant over a period of 60 minutes. During beef insulin infusion the mechanism for beef insulin capture in the liver behaved as though governed by a first-order system, and was not saturated by arterial plasma beef insulin levels of $250 \mu \mathrm{U}$ per $\mathrm{ml}$.

5. A definite peripheral insulin uptake of endogenous and exogenous insulin was demonstrated. The $(\mathrm{A}-\mathrm{V}) / \mathrm{A}$ ratios are smaller and more variable than the equivalent ratios across the liver.

6 . The calculated mean velocity constant of elimination $(k)$ for the infused insulin was 0.02 minute $^{-1}$.

\section{APPENDIX}

In a first-order reaction the infused substance is eliminated at a rate proportional to the amount of the substance present in the plasma. The linear equation expressing this state is:

$$
\frac{d c}{d t}+k c=\frac{p}{v}
$$

where $c=$ concentration of insulin in plasma, $p=$ rate of infusion which is known and constant, $v=$ volume of distribution which is assumed to be constant, and $k=$ velocity constant of elimination. If $c=c_{1}$ when $t=0$, integration yields :

$$
c=\frac{p}{k v}-\frac{\left(p-k v c_{1}\right)}{k v} e^{-k\left(t-t_{0}\right)}
$$

and if $c=0$ when $t=0$, then:

$$
c=\frac{p}{k v}\left(1-e^{-k t}\right)
$$

The hypothetical equilibrium concentration, $C_{2}$ (the $y$ asymptote), was estimated as the value that yielded a straight line when $\log \left(C_{2}-C\right)$ was plotted against time. The best fit for $C_{2}$ was $350 \mu \mathrm{U}$ insulin per $\mathrm{ml}$ when $C$ was regarded as the rise in plasma insulin concentration above the mean preinfusion level of $25 \mu \mathrm{U}$ per ml.

\section{ACKNOWLEDGMENTS}

We are very grateful to Drs. S. Shaldon, J. J. Caesar and L. Chiandussi, who conducted the hepatic vein catheterization and blood flow studies.

\section{REFERENCES}

1. Yalow, R. S., and Berson, S. A. Assay of plasma insulin in human subjects by immunological methods. Nature (Lond.) 1959, 184, 1648.

2. Yalow, R. S., and Berson, S. A. Immunoassay of endogenous plasma insulin in man. J. clin. Invest. $1960,39,1157$.

3. Arquilla, E. R., and Stavitsky, A. B. The production and identification of antibodies to insulin and their use in assaying insulin. J. clin. Invest. 1956, 35, 458.

4. Berson, S. A., and Yalow, R. S. Species-specificity of human anti-beef, pork insulin serum. J. clin. Invest. 1959, 38, 2017.

5. Samols, E., and Williams, H. S. Trace labelling of insulin with iodine. Nature (Lond.) In press.

6. Berson, S. A., and Yalow, R. S. Recent studies on insulin-binding antibodies. Ann. N. Y. Acad. Sci. 1959, 82, 338.

7. Bradley, S. E., Ingelfinger, F. J., Bradley, G. P., and Curry, J. J. The estimation of hepatic blood flow in man. J. clin. Invest. 1945, 24, 890.

8. Caesar, J. J., Shaldon, S., Chiandussi, L., Guevara, L., and Sherlock, S. The use of indocyanine green in the measurement of hepatic blood flow and as a test of hepatic function. Clin. Sci. 1961, 21, 43.

9. Madison, L. L., Combes, B., Adams, R., and Strickland, W. The physiological significance of the secretion of endogenous insulin into the portal circulation. III. Evidence for a direct immediate effect of insulin on the balance of glucose across the liver. J. clin. Invest. 1960, 39, 507. 
10. Young, F. G. The nature and mechanism of action of hormones in Ciba Foundation Tenth Anniversary Symposium on Significant Trends in Medical Research, G. E. W. Wolstenholme, C. M. O'Connor and M. O'Connor, Eds. London, Churchill, 1959, p. 135.

11. Gardiner, D. C., Martin-Hernandez, D., and Young, F. G. Influence of oxygenation and deoxygenation on distribution of insulin activity among bloodplasma-protein fractions. Lancet 1960, 2, 1269.

12. Groen, J., Kamminga, C. E., Willebrands, A. F., and Blickman, J. R. Evidence for the presence of insulin in blood serum. A method for an approximate determination of the insulin content of blood. J. clin. Invest. 1952, 31, 97.

13. Vallance-Owen, J., and Hurlock, B. Estimation of plasma-insulin by the rat diaphragm method. Lancet 1954, 1, 68.

14. Willebrands, A. F., v. d. Geld, H., and Groen, J. Determination of serum insulin using the isolated rat diaphragm. The effect of serum dilution. Diabetes 1958, 7, 119.

15. Martin, D. B., Renold, A. E., and Dagenais, Y. M. An assay for insulin-like activity using rat adipose tissue. Lancet 1958, 2, 76.

16. Randle, P. J. Assay of plasma insulin activity by the rat-diaphragm method. Brit. med. J. 1954, 1, 1237.

17. Anderson, E., Lindner, E., and Sutton, V. A sensitive method for the assay of insulin in blood. Amer. J. Physiol. 1947, 149, 350.
18. Baird, C. W., and Borstein, J. Assay of insulin-like activity in the plasma of normal and diabetic human subjects. J. Endocr. 1959, 19, 74.

19. Grodsky, G. M., and Forsham, P. H. Comparative binding of beef and human insulin to insulin antibodies produced in man and guinea pigs. $\mathrm{J}$. clin. Invest. 1961, 40, 799.

20. Mortimore, G. E., and Tietze, F. Studies on the mechanism of capture and degradation of insulin$\mathrm{I}^{131}$ by the cyclically perfused rat liver. Ann. N. Y. Acad. Sci. 1959, 82, 329.

21. Madison, L. L., Combes, B., Unger, R. H., and Kaplan, $N$. The relationship between the mechanism of action of the sulfonylureas and the secretion of insulin into the portal circulation. Ann. N. Y. Acad. Sci. 1959, 74, 548.

22. Samols, E., and Beckett, G. Unpublished data.

23. Jokipii, S. G., and Turpeinen, O. Kinetics of elimination of glucose from the blood during and after a continuous intravenous injection. $\mathrm{J}$. clin. Invest. 1954, 33, 452.

24. Lauson, H. D. Vasopressin and oxytocin in the plasma of man and other mammals in Hormones in Human Plasma, H. N. Antoniades, Ed. Boston, Little, Brown, 1960.

25. Berson, S. A., Yalow, R. S., Bauman, A., Rothschild, M. A., and Newerly, K. Insulin- ${ }^{131}$ metabolism in human subjects: Demonstration of insulin binding globulin in the circulation of insulin treated subjects. J. clin. Invest. 1956, 35, 170. 